\title{
Streptococcus macacae sp. nov. from Dental Plaque of Monkeys (Macaca fascicularis)
}

\author{
D. BEIGHTON, ${ }^{1 *}$ H. HAYDAY, ${ }^{1}$ R. R. B. RUSSELL, ${ }^{1}$ AND R. A. WHILEY ${ }^{2}$ \\ Royal College of Surgeons of England, Dental Research Unit, West Hill, Downe, Orpington, Kent, ${ }^{1}$ and The London \\ Hospital Medical College, Dental School, Department of Oral Microbiology, London, EI $2 A D,{ }^{2}$ United Kingdom
}

\begin{abstract}
We propose the name Streptococcus macacae sp. nov. for gram-positive, catalase-negative streptococcal strains that were isolated from the dental plaque of monkeys (Macaca fascicularis). This organism is distinct from other oral streptococci in that it produces acid from mannitol and raffinose but not from inulin or dextrin. It is not able to grow in the presence of bacitracin and does not produce hydrogen peroxide or hydrolyze arginine, but esculin is hydrolyzed, and dextran is produced from sucrose. Streptococcus macacae $\mathrm{sp}$. nov. possesses the serotype $c$ antigen described by Bratthall, as do Streptococcus mutans and Streptococcus ferus; however, the protein profiles of whole-cell extracts subjected to sodium dodecyl sulfate-polyacrylamide gel electrophoresis and differences in deoxyribonucleic acid composition demonstrate that the new isolates are distinct from the two other species that possess the serotype $c$ antigen and from other mutans streptococci. The guanine-plus-cytosine content of $S$. macacae is 35 to 36 mol\%. The type strain is strain 25-1 (- NCTC 11558).
\end{abstract}

During the course of studies into the ecology of streptococci in the dental plaque of monkeys (Macaca fascicularis), we isolated organisms that differ from any previously reported species. These streptococci are mutans streptococci in that they produce acid from mannitol, form dextran from sucrose, and have the teeth as their major oral habitat (5). The biochemical and genetic differences between the new isolates and previously described mutans streptococcal species lead us to propose that the new strains represent a distinct species.

\section{MATERIALS AND METHODS}

Bacterial strains. The strains used in this study are listed in Table 1.

Methods of characterization. The phenotypic reactions of strains were studied by using media and methods which we have described previously (1). Additionally, we incorporated into our conventional identification system a test for acid production from dextrin which Kral and Daneo-Moore (12) found, using a miniaturized system, enabled differentiation of Streptococcus ferus from Streptococcus mutans. We found that $S$. ferus strains HD3 and $8 \mathrm{SI}^{\mathrm{T}}$ ( $\mathrm{T}=$ type strain) gave the same results in our test system as previously reported (12).

Determination of DNA base composition. To determine deoxyribonucleic acid (DNA) base composition, approximately $2 \mathrm{~g}$ (wet weight) of bacteria were lysed and treated by the method of Garvie (9) up to the step involving incubation with ribonuclease (final concentration, $50 \mu \mathrm{g} / \mathrm{ml}$; type XIV; Sigma Chemical Co.), and incubation was continued for an additional $60 \mathrm{~min}$. The solution was deproteinized by shaking with an equal volume of chloroform-octanol (24:1) and then centrifuged at $5,000 \mathrm{rpm}$ for $10 \mathrm{~min}$, and the upper aqueous layer was passed through a column $(1 \mathrm{by} 10 \mathrm{~cm})$ of Sepharose $4 \mathrm{~B}$ that was irrigated with standard saline citrate $(0.15 \mathrm{M} \mathrm{NaCl}$ plus $0.015 \mathrm{M}$ trisodium citrate, $\mathrm{pH} 7.0$ ) at a flow rate of $0.1 \mathrm{ml} / \mathrm{min}(10)$. Fractions $(2 \mathrm{ml})$ were collected, and the fraction corresponding to the first peak eluted from the column (determined by absorbance readings at $260 \mathrm{~nm}$ ) was used to determine the guanine-plus-cytosine $(\mathrm{G}+\mathrm{C})$

\footnotetext{
* Corresponding author.
}

content of the DNA. The thermal melting point of each DNA sample was determined in triplicate with a Gilford model 240 spectrophotometer at $260 \mathrm{~nm}$ by using a Gilford model 2527 thermoprogrammer with a heating rate of $1^{\circ} \mathrm{C} / \mathrm{min}$. DNAs isolated from $S$. mutans strain NCTC $10449^{\mathrm{T}}$ and Streptococcus rattus strain $\mathrm{FA}-1^{\mathrm{T}}$ were used for reference.

Intraoral distribution. Plaque samples from the developmental grooves of premolar teeth and tongue swabbings were taken from eight monkeys and treated as previously described (1) in order to isolate streptococci.

Serological procedures. Antisera were raised by giving rabbits multiple injections of heat-killed bacteria as described by Bratthall (2). Immunodiffusion tests were performed by using glass slides coated with $1 \%(\mathrm{wt} / \mathrm{vol})$ agarose in $0.5 \mathrm{M}$ tris(hydroxymethyl)aminomethane hydrochloride buffer $(\mathrm{pH} \mathrm{7.5)}$. The sample wells were $4 \mathrm{~mm}$ in diameter and $4 \mathrm{~mm}$ apart and had a volume of $20 \mu \mathrm{l}$. Serotyping was performed by using the bacteria collected by centrifugation from $20 \mathrm{ml}$ of a Todd-Hewitt broth (Oxoid Ltd.) culture as antigen (1).

Polysaccharide antigen extraction. Polysaccharides were prepared by hot phenol extraction of lyophilized cells (21). For purification of antigen, the polysaccharide preparation was applied to a column of diethylaminoethyl-Trisacryl $\mathrm{M}$ (LKB products Ltd.) in $0.5 \mathrm{M}$ tris(hydroxymethyl)aminomethane hydrochloride buffer $(\mathrm{pH} 7.5)$. The column was eluted with a gradient of increasing concentrations of $\mathrm{NaCl}$. The antigen contents of the eluted fractions were monitored by immunodiffusion.

The sugar contents of the polysaccharides were determined by hydrolyzing samples in $3 \mathrm{M} \mathrm{HCl}$ for $3 \mathrm{~h}$ at $105^{\circ} \mathrm{C}$, removing the acid by evaporation, and subjecting the hydrolysates to thin-layer chromotography (16).

SDS-PAGE of cell extracts. The polyacrylamide gel electrophoresis (PAGE) patterns of sodium dodecyl sulfate (SDS) extracts of the new isolates were compared with the patterns of the other mutans streptococci by using previously described methods $(1,19)$.

\section{RESULTS AND DISCUSSION}

The 10 monkey isolates examined were gram-positive cocci that grew in chains and were isolated primarily from 
TABLE 1. Strains used

\begin{tabular}{|c|c|c|}
\hline Species & Serotype & $\operatorname{Strain}(s)^{h}$ \\
\hline \multirow[t]{3}{*}{ S. mutans } & $c$ & Ingbritt, NCTC $10449^{\mathrm{T}}$ \\
\hline & $e$ & $\mathrm{P} 4$ \\
\hline & $f$ & 151 \\
\hline \multirow[t]{3}{*}{ Streptococcus sobrinus } & $d$ & B13 \\
\hline & $g$ & K1 \\
\hline & $h$ & MFe28 (= NCTC 11391) \\
\hline Streptococcus cricetus & $a$ & NCTC $10919^{\mathrm{T}}$ \\
\hline S. rattus & $b$ & NCTC $10920^{\mathrm{T}}$ \\
\hline S. ferus & $c$ & $\mathrm{HD} 3,8 \mathrm{SI}^{\mathrm{T}}$ \\
\hline S. macacae & $c$ & $\begin{array}{l}25-1^{\mathrm{T}}\left(=\text { NCTC } 11558^{\mathrm{T}}\right), \mathrm{B} 1107, \\
653, \mathrm{H} 1569, \mathrm{~B} 1435, \mathrm{H} 1670, \\
2638 \mathrm{a}, 2583 \mathrm{~d}, 2632,2532 \mathrm{a}, \\
\mathrm{H} 1727\end{array}$ \\
\hline
\end{tabular}

${ }^{a}$ Serotypes $a, b, c, d$, and $e$ are described by Bratthall (3), serotypes $f$ and $g$ are described by Perch et al. (17), and serotype $h$ is described by Beighton et al. (1).

${ }^{b}$ With two exceptions, the $S$. mutans, $S$. sobrinus, $S$. cricetus, and $S$. rattus strains were obtained from J. M. Hardie, London Hospital Medical College, London, United Kingdom: S. mutans strain Ingbritt was obtained from $\mathrm{G}$. Colman, and $S$. sobrinus strain $\mathrm{MFe} 28$ was isolated in our laboratory. The $S$. ferus strains were obtained from A. L. Coykendall, and all of the $S$ macacae strains were isolated in our laboratory.

dentition rather than tongues. They produced acid from mannitol and dextrin from sucrose but were unable to form $\mathrm{H}_{2} \mathrm{O}_{2}$ or grow in the presence of $6.5 \% \mathrm{NaCl}$. These are characteristics of mutans streptococci (5). These isolates were similar to two previously described species, $S$. mutans and $S$. ferus, in that they possessed the serotype $c$ antigen described by Bratthall (3); the composition of the antigen also resembled the composition of the antigen of $S$. mutans $(15,22)$. However, an examination of the biochemical and physiological characteristics of the new isolates by using the scheme of Kral and Daneo-Moore (12) showed that they differed from $S$. mutans in their inability to grow in the presence of bacitracin. They differed from $S$. ferus in that they produced acid from raffinose but failed to produce acid from dextrin or starch. Other differences were also apparent as the new isolates failed to produce acid from inulin, whereas both $S$. mutans and $S$. ferus did so, and only $S$. ferus produced acid from glycogen.

Data obtained with SDS-PAGE extracts of the mutans

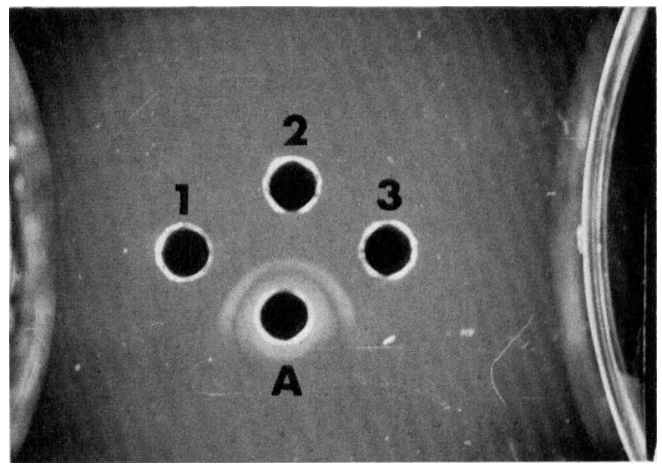

FIG. 1. Immunodiffusion. $S$. mutans serotype $c$-specific antiserum raised against $S$. mutans strain Ingbritt (well A) was tested against pelletted whole cells of $S$. mutans strain Ingbritt (well 1), $S$. ferus strain $8 \mathrm{SI}$ (well 2), and $S$. macacae strain $25-1^{\mathrm{T}}$ (well 3 ).

streptococci $(1,19)$ have supported the proposal of Coykendall (5) for the establishment of distinct species within this heterogeneous group of oral streptococci. The protein profiles obtained with SDS-PAGE of the serotype $c$-bearing strains have demonstrated the distinctness of $S$. ferus and $S$. mutans, and this supports our proposal that the new monkey isolates represent a distinct species.

The composition of the DNAs from the monkey isolates indicated a mean $\mathrm{G}+\mathrm{C}$ content of 35 to $36 \mathrm{~mol} \%$, whereas the $\mathrm{G}+\mathrm{C}$ content of $S$. mutans is 36 to $38 \mathrm{~mol} \%$ and that of $S$. ferus is 42 to $44 \mathrm{~mol} \%$. Although we have not performed DNA homology studies, the differences in the DNA compositions indicate the separateness of the three groups of streptococci that possess the serotype $c$ polysaccharide antigen.

We conclude that the monkey strains are different from other mutans streptococci and represent a new species, for which we propose the name Streptococcus macacae sp. nov. (ma.cacae.M.L.fem.n.Macaca genus name of macaque; M.L. gen.n.macacae of macaque). The type strain is strain 25-1 (= NCTC 11558).

Morphology and growth characteristics of $S$. macacae. $S$. macacae cells are gram-positive cocci which grow in chains

TABLE 2. Differential characteristics of $S$. macacae and other mutans streptococci

\begin{tabular}{|c|c|c|c|c|c|c|}
\hline Characteristic & S. macacae & S. mutans & S.ferus & S. sobrinus & S. cricetus & S. rattus \\
\hline $\begin{array}{l}\mathrm{G}+\mathrm{C} \text { content of DNA } \\
(\mathrm{mol} \%)^{a}\end{array}$ & $35-36$ & $36-38$ & $43-45$ & $44-46$ & $42-44$ & $41-43$ \\
\hline Serotype $(\mathrm{s})^{b}$ & $c$ & $c, e, f$ & $c$ & d. $g, h$ & $a$ & $b$ \\
\hline Cell wall carbohydrates ${ }^{c}$ & $\begin{array}{l}\text { Glucose, } \\
\text { rhamnose }\end{array}$ & $\begin{array}{l}\text { Glucose, } \\
\text { rhamnose }\end{array}$ & $\begin{array}{l}\text { Not } \\
\text { known }\end{array}$ & $\begin{array}{l}\text { Glucose, } \\
\text { galactose, } \\
\text { rhamnose }\end{array}$ & $\begin{array}{l}\text { Glucose, } \\
\text { galactose, } \\
\text { rhamnose }\end{array}$ & $\begin{array}{l}\text { Galactose, } \\
\text { rhamnose }\end{array}$ \\
\hline \multicolumn{7}{|l|}{ Acid production from: ${ }^{d}$} \\
\hline Dextrin & - & - & + & - & - & - \\
\hline Glycogen & - & - & + & $\mathrm{ND}^{\prime}$ & ND & ND \\
\hline Inulin & - & + & + & $-t$ & + & + \\
\hline Raffinose & + & + & - & - & + & + \\
\hline Starch & - & - & + & - & - & - \\
\hline Resistance to bacitracin ${ }^{d}$ & - & + & - & $+{ }^{\prime}$ & - & + \\
\hline $\mathrm{H}_{2} \mathrm{O}_{2}$ production ${ }^{d}$ & - & - & - & $+^{t}$ & - & - \\
\hline Arginine hydrolysis ${ }^{d}$ & - & - & - & - & - & + \\
\hline
\end{tabular}

"Data from references 4 and 7 .

${ }^{h}$ Data from references 1,3 , and 17 .

"Data from reference 11 .

${ }^{d}$ Data from reference 12 .

ND. Not determined.

$f$ Serotype $h$ strains produce acid from inulin, are not resistant to bacitracin, and do not produce $\mathrm{H}_{2} \mathrm{O}_{2}(1)$. 
TABLE 3. S. macacae occurrence as a percentage of the total anaerobic colony count in the dental plaque and on the tongues of monkeys fed a sucrose-rich diet ${ }^{a}$

\begin{tabular}{ccc}
\hline Monkey no. & $\begin{array}{c}\text { \% of total } \\
\text { count in } \\
\text { plaque }\end{array}$ & $\begin{array}{c}\text { \% of total } \\
\text { count on } \\
\text { tongue }\end{array}$ \\
\hline 1 & 2.7 & $\mathrm{ND}^{b}$ \\
2 & 28.4 & 6.6 \\
3 & 5.3 & $\mathrm{ND}$ \\
4 & 8.2 & $\mathrm{ND}$ \\
5 & 32.6 & $\mathrm{ND}$ \\
6 & 24.4 & $\mathrm{ND}$ \\
7 & 22.1 & $\mathrm{ND}$ \\
8 & 10.3 & $\mathrm{ND}$ \\
\hline
\end{tabular}

${ }^{a}$ See reference 1 .

${ }^{b}$ ND, Not detected (detection level, $0.05 \%$ ).

in Todd-Hewitt broth and on sucrose-containing solid medium. The strains grow poorly in air, but growth is stimulated by the presence of $\mathrm{CO}_{2}$; hence, growth occurs in candle jars and in anaerobe jars fitted with cold Deoxy catalyst (Oxoid) in an atmosphere initially consisting of $90 \%(\mathrm{vol} / \mathrm{vol}) \mathrm{H}_{2}$ and $10 \%(\mathrm{vol} / \mathrm{vol}) \mathrm{CO}_{2}$.

On sucrose-containing medium the colonies are easily removed but coherent. They are transparent and 1 to $2 \mathrm{~mm}$ in diameter after 3 days of incubation. As with other mutans streptococci (8), a less frequent colony form is produced, which is vivid white, less than $1 \mathrm{~mm}$ in diameter, erose, crumbly, and easily removed from the medium with a loop. The transparent forms always give rise to the two colony types, but the vivid white forms retain their original colonial morphology despite repeated streaking onto fresh medium. Strains produce greening of horse blood agar plates whether they are grown anaerobically or in candle jars.

Biochemical characteristics. The strains examined all give similar results in the tests which we performed. Acid is produced from $\mathrm{N}$-acetyl glucosamine, amygdalin, cellobiose, fructose, glucose, galactose, maltose, sucrose, and trehalose; sorbitol is fermented slowly. The terminal $\mathrm{pH}$ in sucrose broth varies from 4.6 to 4.9 . No acid is produced from adonitol, arabinose, glycerol, inositol, melezitose, melibiose, ribose, sorbose, xylitol, or xylose. Additional characteristics are shown in Table 2. Dextran is produced from sucrose, and catalase is not produced; $\mathrm{H}_{2} \mathrm{O}_{2}$ is not produced. Growth occurs in media containing 10 and $40 \%$ (wt/vol) bile but not in the presence of $6.5 \%(\mathrm{wt} / \mathrm{vol}) \mathrm{NaCl}$, at $45^{\circ} \mathrm{C}$, or at $\mathrm{pH}$ 9.6. Esculin is hydrolyzed; starch and blue dextran are weakly hydrolyzed, and arginine is not hydrolyzed.

Serotype $c$ antigen. The strains of $S$. mutans, $S$. macacae, and $S$. ferus all contain an antigen which forms a precipitin line of identity when a bacterial pellet one of the strains is tested in an immunodiffusion assay with typing sera raised against $S$. mutans (three different sera) or strain $25-1^{\mathrm{T}}$ (Fig. 1). No other precipitin lines are observed with a wide range of antiserum concentrations and varying amounts of bacterial pellet. This antigen can be extracted from the bacteria by the Lancefield (14), Rantz-Randall (18), and hot phenolwater (21) procedures and has been purified by ion-exchange chromatography on diethylaminoethyl-Trisacryl. The serotype $c$ antigen elutes at approximately $0.1 \mathrm{M} \mathrm{NaCl}$. Glucose and rhamnose are the major sugars detected after hydrolysis of the antigen, as previously found for $S$. mutans $(15,22)$, although a trace of galactose also is found.

DNA composition. The $\mathrm{G}+\mathrm{C}$ contents of three of the new isolates (strains $\mathrm{H} 1569, \mathrm{H} 1762$, and $25-1^{\mathrm{T}}$ ) are 35 and 36 mol\%, respectively. The values found for $S$. mutans NCTC $10449^{\mathrm{T}}$ and $S$. rattus Fitzgerald $\mathrm{FAl}^{\mathrm{T}}$ are 37 and $42 \mathrm{~mol} \%$. respectively; these values are almost identical to the values found by other workers (5).

Intraoral distribution. The strains of $S$. macacae were isolated primarily from dental plaque samples, indicating that tooth surfaces are the preferred habitat of these organisms (Table 3 ).

SDS-PAGE of cell extracts. The SDS-PAGE profiles of the 11 strains of $S$. macacae were identical and were distinct from the profiles of the other Streptococcus species examined. Figure 2 shows only the difference between the three streptococcal species bearing the serotype $c$ polysaccharide antigen, as these species may be confused if serotyping is used to identify isolates. S. macacae, S. mutans, and $S$.

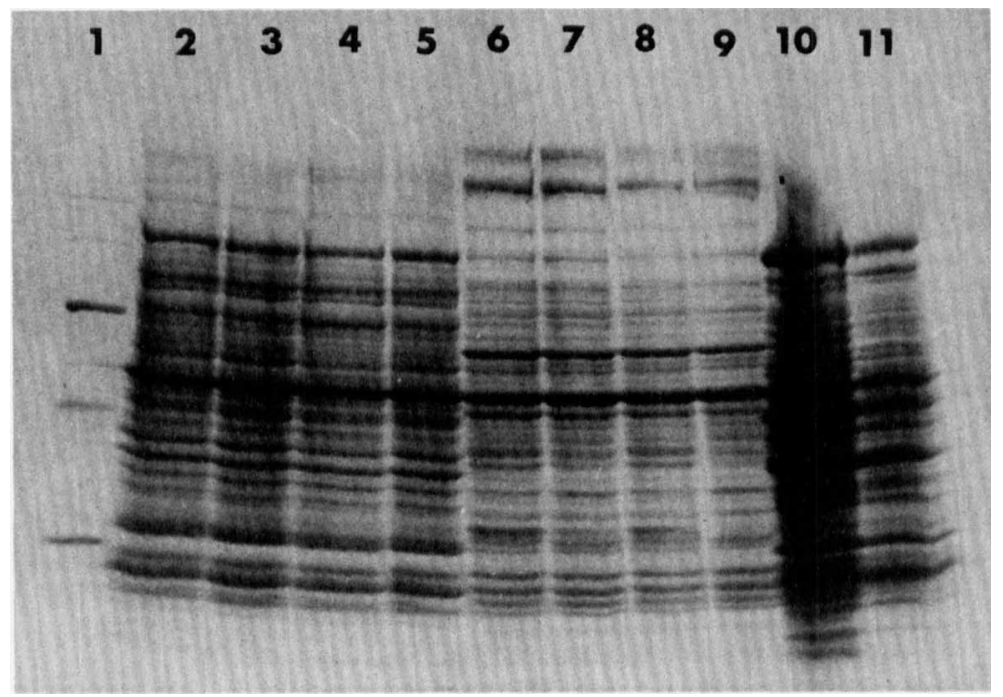

FIG. 2. SDS-PAGE patterns of strains of $S$. mutans serotype $c, S$. macacae, and $S$. ferus. Lane 1 , Molecular weight standards; lanes 2 through 5, S. mutans serotype $c$ strain Ingbritt, strain NCTC $10449^{\mathrm{T}}$, and two fresh monkey isolates, respectively; lanes 6 through $9, S$. macacae strains $25-1^{\mathrm{T}}, \mathrm{B} 1107,653$, and $\mathrm{H} 1569$, respectively; lanes 10 and $11, S$. ferus strains HD3 and $8 \mathrm{SI}^{\mathrm{T}}$, respectively. 
ferus each has a characteristic protein profile that is distinctly different from the profiles of all other mutans streptococci.

\section{LITERATURE CITED}

1. Beighton, D., R. R. B. Russell, and H. Hayday. 1981. The isolation and characterization of Streptococcus mutans serotype $h$ from dental plaque of monkeys (Macaca fascicularis). J. Gen. Microbiol. 124:271-279.

2. Bratthall, D. 1969. Immunodiffusion studies on the serological specificity of streptococci resembling Streptococcus mutans. Odontol. Revy 20:231-243.

3. Bratthall, D. 1970 . Demonstration of five serological groups of streptococcal strains resembling Streptococcus mutans. Odontol. Revy 21:143-152.

4. Coykendall, A. L. 1970. Base composition of deoxyribonucleic acid isolated from cariogenic streptococci. Arch. Oral Biol. 15:365-368.

5. Coykendall, A. L. 1977. Proposal to elevate the subspecies of Streptococcus mutans to species status, based on their molecular composition. Int. J. Syst. Bacteriol. 27:26-30.

6. Coykendall, A. L., D. Bratthall, K. O'Connor, and R. A. Dvarkas. 1976. Serological and genetic examination of some nontypical Streptocorcus mutans strains. Infect. Immun. 14:667-670.

7. Dunny, G. M., T. Hausner, and D. B. Clewell. 1972. Buoyant densities of DNA from various strains of Streptococcus mutans. Arch. Oral Biol. 17:1001-1003.

8. Edwardsson, S. 1968. Characteristics of caries-inducing human streptococci resembling Streptococcus mutans. Arch. Oral Biol. 13:637-646.

9. Garvie, E. I. 1976. Hybridization between the deoxyribonucleic acids of some strains of heterofermentative lactic acid bacteria. Int. J. Syst. Bacteriol. 26:116-122.

10. Gibson, D. M., and I. D. Ogden. 1979. A rapid method for purifying bacterial deoxyribonucleic acid. J. Appl. Bacteriol.
46:421-423.

11. Hamada, S., and H. D. Slade. 1980. Biology, immunology, and cariogenicity of Streptococcus mutans. Microbiol. Rev. 44:331384.

12. Kral, T. A., and L. Daneo-Moore. 1981. Biochemical differentiation of certain oral streptococci. J. Dent. Res. 60:1713-1718.

13. Krasse, B. 1966. Human streptococci and experimental caries in hamsters. Arch. Oral Biol. 11:429-436.

14. Lancefield, E. 1933. A serological differentiation of human and other groups of hemolytic streptococci. J. Exp. Med. 57:571595.

15. Linzer, R., K. Gill, and H. D. Slade. 1976. Chemical composition of Streptococcus mutans type $c$ antigen: comparison to type $a, b$ and $d$ antigens. J. Dent. Res. 55:A109-A115.

16. Menzies, I. S., and J. N. Mount. 1975. Advantages of silica gel as a medium for rapid thin-layer chromatography of neutral sugars. Med. Lab. Technol. 32:269-276.

17. Perch, B., E. Kjems, and T. Ravn. 1974. Biochemical and serological properties of Streptococcus mutans from various human and animal sources. Acta Pathol. Microbiol. Scand. Sect. B 82:357-370.

18. Rantz, L. A., and E. Randall. 1955. Use of autoclaved extracts of hemolytic streptococci for serological grouping. Stanford Med. Bull. 13:290-291.

19. Russell, R. R. B. 1976. Classification of Streptococcus mutans strains by SDS gel electrophoresis. Microbios Lett. 2:55-59.

20. Russell, R. R. B. 1979. Comparison of oral Streptococcus mutans AHT with strains of serotypes $a$ and $g$ by biochemical and electrophoretic methods. Arch. Oral Biol. 24:617-619.

21. Westphal, O., and K. Jann. 1965. Bacterial lipopolysaccharides. Extraction with phenol-water and further applications of the procedure. Methods Carbohydr. Chem. 5:83-91.

22. Wetherell, J. R., Jr., and A. S. Bleiweis. 1975. Antigens of Streptococcus mutans: characterization of a polysaccharide antigen from walls of strain GS-5. Infect. Immun. 12:1341-1348. 